\title{
A Study of Students' Reading Interests in a Second Language
}

\author{
Zurina Khairuddin ${ }^{1}$ \\ ${ }^{1}$ School of English Language Studies, Universiti Sultan Zainal Abidin, Terengganu, Malaysia \\ Correspondence: Zurina Khairuddin, School of English Language Studies, Universiti Sultan Zainal Abidin, \\ 21300, Kuala Terengganu, Terengganu, Malaysia. Tel: 609-668-8062. E-mail: zkzurina@unisza.edu.my
}

Received: September 23, 2013 Accepted: October 14, 2013 Online Published: October 31, 2013

doi:10.5539/ies.v6n11p160

URL: http://dx.doi.org/10.5539/ies.v6n11p160

\begin{abstract}
Reading interests is important in enhancing students' success in school and out of it. Hence, students need to have high reading interests. The purposes of this study were to identify students' reading interests in reading second language materials and to examine the differences in students' reading interests based on genders. This study was carried out among 86 Form Four students in Kuala Terengganu with simple random sampling using an6-item questionnaire adapted and adopted from Marrero (2009). Data were analysed as well as presented in the form of frequency, means, standard deviation and independent $\mathrm{t}$ - test. From this study, it is found that students have relatively low interests in reading English materials and that there is a significant difference between male and female students. From these findings, it can be suggested that stakeholders should take action with regards to developing and enhancing male students' reading interests. It is hoped that the finding of this study would enlighten the relevant literature of the area.
\end{abstract}

Keywords: students' reading interests, secondary school students, second language materials, Terengganu, gender

\section{Introduction}

It is said that reading is the path to success in school and life. One who is not able to read will not be able to succeed (U. S. Department of Education, 2005). This is supported by Safiah (1990) who mentioned that those who are good readers are able to expand their views, experiences and thoughts. Hence, reading is viewed as a highly valued skill in our technology-driven world today. The US Department of Education (2005) also stated that reading is one of the means to gain access to all the knowledge in this world. Living in a largely literate society, we are surrounded by written materials covering almost all aspects of our lives. Examples of written materials are newspapers, books, journals, magazines and other electronic sources which are utilized to acquire knowledge as today's technology-literate societies operate on the foundation that the members of the society are literate (Wallace, 1992). Wallace (1992) also mentioned that reading has become a big part of the public's daily life especially now that literacy is given emphasis. This is also maintained by Imran Ariff (2010) who stated that today's technology-oriented world puts emphasis on knowledge and hence the importance of reading. He also added that knowledge gained will attract people to read and to increase their knowledge. Accordingly, if people do not succumb to the demand for higher literacy, it may create grievous consequences to them. In addition to that, according to Abd Wahab (1995), if Malaysians were to adopt the reading habit, there is a possibility that the Vision 2020 could be achieved. However, Imran Ariff (2010) pointed out that although Malaysians are reported to read more nowadays, they have not adopted the habit of reading.

Although reading has a lot of benefits, Malaysians in general and students particularly still do not adopt reading habit (Imran Ariff, 2010; Safiah, 1990). This worries stakeholders such as parents, teachers and society. Accordingly, understanding students' reading interest in reading English materials and the factors that lead to having high or low reading interest will assist parents, teachers and the society to address students' reading needs more effectively and thus to raise their attainment towards reading. The awareness among these stakeholders on the importance of identifying students' reading interest towards reading in a second language can influence students' reading achievement in English classes (Marohaini, 1989; McKenna \&Kear, 1990). Marohaini (1989) added that because of this situation, the stakeholders will establish programs, techniques, strategies or ways to inculcate, develop and enhance students' reading interests. 
Therefore, this study was conducted to identify students' reading interests in reading English materials and to examine if there are any differences in students' reading interests based on their gender.

\subsection{Research Problem}

Reading is a skill that must be learned, yet the process of learning to read can become pleasurable and easy for some students or displeasing and complicated for others. Some will employ reading as a learning opportunity while others will avoid it because they find it complex and they struggle at it (Wallace, 2007). This could be the reason why students nowadays are said to be lacking the interest in reading (Ley, Schaer \& Dismukes, 1994). This is also supported by Safiah (1990) who mentioned that students nowadays lack the interest in reading. A Malaysian Reading Profile Survey conducted in 2010 also reported that Malaysians who are at the age of 10 and above only read approximately eight to twelve books a year (National Library of Malaysia, 2010). This number is worrisome (Imran Ariff, 2010). He also stated that students nowadays have higher interests in reading; nonetheless, they still do not adopt reading as a habit.

Furthermore, students might have difficulties in learning English as a second language (Nunan, 1999). Those who have a negative experience in learning a second language may feel frustrated and angry when reading English texts. These factors, coupled with the embarrassment of not performing well in the language or failure to keep up with other students may create a damaging situation for the students. They might end up become less interested in reading English materials. Therefore, they will not adopt reading in a second language as a habit.

Students' failure to cultivate the reading habit is a major problem (Abd Wahab, 1995). This is due to the fact that students who do not read will have problems academically. In addition to that, students nowadays, including the good ones, do not read for pleasure (Safiah, 1990). It is believed that students read not because they want to read, but because they have to read. Students perceive reading as a task that they have to undertake in order to excel academically. Furthermore, secondary school students are busy with extra co curricular activities and they also have other personal problems such as they need to take care of their younger siblings or help their parents with house chores (Abd Wahab, 1995). This could create problems as secondary school students including good students tend to lose their interest in reading as they mature (Safiah, 1990). This is maintained by Ley, Schaer and Dismukes (1994) who discovered that a lot of middle school grade students show a remarkable decline in general attitudes towards reading, intrinsic motivation for reading and the frequency of voluntary reading.

According to the Malaysian Reading Profile Survey, 93\% of Malaysians are literate (National Library of Malaysia, 1998). However, a lot of Malaysians have yet to adopt the habit of reading (Imran Ariff, 2010). In other words, there is quite a number of Malaysians still do not read for pleasure nor they read when they have the time. This is proven by the Malaysian Reading Profile Survey conducted by the National Library of Malaysia (1998) in 1996, which indicated that only $87 \%$ of Malaysians adopt the habit of reading in which this number is meant for reading in both the first and second language. Apart from that, according to this reading profile, only $29 \%$ of the population uses the library and this is a very small number. In addition to that, $22 \%$ of Malaysians develop their ability to read through television or the video medium instead of through reading books or other reading materials. This shows that Malaysians prefer to watch televisions or videos than read. Similar findings were found by Kaur and Thivagarajah (1999) who revealed that Malaysian students preferred to watch television and videos compared to reading for pleasure and as a result, they read very little. Other than that, another research found that the majority of the students were considered as reluctant readers when it came to reading second language materials (Pandian, 2000).

Additionally, it is found that university students spent a significant amount of time in reading newspapers, academic books and websites due to the demands from doing assignments, instead of for pleasure (Nor Shariza \& Amelia, 2007). In the Malaysian Reading Profile Survey in 2010, it was revealed that Malaysians above 10 years old read at the average of eight to twelve books a year (National Library of Malaysia, 2010). Apart from that, the reading habit in Malaysia is still considered an issue although $93 \%$ of Malaysians are literate (Imran Ariff, 2010). Senu (2002, as cited in Imran Ariff, 2010) also mentioned that every family in Malaysia only spends RM50 yearly to buy books and this is a small amount of money to be spent on reading materials. This shows Malaysians still have not adopted the habit of reading. A study by Imran Ariff (2010) discovered that students have interests in reading, however, they have not reached to a point where they take reading as a habit. A research conducted by Mohamad Jafre, Majid and Ooi who investigated the reading interests of Chinese Malaysian students found that $48 \%$ of the respondents in the study stated that they read during their spare time (2011). These students mentioned that they mostly read newspapers, magazines and comics (Mohamad Jafre, Majid and Ooi, 2011). However, it is also found that only $20 \%$ of the respondents read to pass time and $10 \%$ indicated that they read because they believe reading is fun (Mohamad Jafre, Majid and Ooi, 2011). In addition 
to this, the result of this research also indicated that the only two students out of 60 students read novels or story books for more than four hours per day (Mohamad Jafre, Majid and Ooi, 2011). These findings show that Malaysian Chinese students still do not adopt the habit of reading for pleasure.

This is one of the major issues parents, teachers and the society are concerned of (Marohaini, 1989). Furthermore, it is an area a few researchers have studied on especially in the area of Kuala Terengganu. In order to bridge the niche, this study would investigate this problem by identifying students' reading interests in reading English materials and examining if there are any differences in students' interests based on their genders. As a result of this study, it would be able to help parents and teachers to know their children or students better. By identifying the results of this study, parents would know that they need to emphasize the importance of learning English and reading second language materials. The findings of this study could also assist parents to identify whether what they do at home contributes to the development of their children's reading habit and interest such as reading aloud or providing a wide range of reading materials for their children.

\subsection{Reading Interests}

Through reading, one has access to a wide range of knowledge found in various reading materials like academic books, magazines, newspapers and journals (US Department of Education, 2005). One who does not know how to read or does not like to read will likely be archaic as he or she fails to benefit from the opportunity to gain access to the wide range of knowledge. Besides, when readers read to get information, they indirectly improve their reading skills. This is supported by Eskey (2002) who stated that by reading, one learns to read and becomes better at reading. Due to this, people who read extensively can become good readers as they are exposed to new words. As a result, they will like reading and become successful.

The early experience ESL students encounter when reading second language materials could determine their attitudes towards reading (Marrero, 2009). She also stated that students will employ the attitude that they have adopted towards reading in a second language as they advance to the development stages of reading (2009). Furthermore, students in the English language classroom come from different cultures and backgrounds (Grabe, 2003). Due to this, they vary in terms of their reading interest in English reading materials.

According to Mc Kool (2007), reading interest is defined as readings done when students are outside the school compound. Furthermore, the US Department of Education (2005) defined reading interests as whether or not students like to read in their spare time or at home or whether they like to go to the library. Besides, reading interest is also defined by the number of books read in a month and the number of times students read in a week and the favourite genres and types of English reading materials.

According to research conducted by Taylor, Frye and Maruyama (1990), Anderson, Fielding and Wilson (1988), Stanovich (1986) and Walberg and Tsai (1984), reading interest has a strong positive relationship with the success of students both in school and life. When students read, they will gain more knowledge and this will help them to have wider and broader perspectives on certain issues. Besides, Anderson, Fielding and Wilson (1988) found that students' reading interest is one of the best predictors of a child's growth in reading. In addition, other research also revealed that reading interest has been linked and related to vocabulary development, comprehension, fluency as well as general intellectual development (Guthrie \& Wigfield, 2000; Taylor, Frye \& Maruyama, 1990; Anderson, Fielding \& Wilson, 1988; Stanovich, 1986). Consequently, reading interest is also linked to academic success as students who love to read will be able to write well and have more ideas which will make them more creative and innovative (Grabe, 2003; Stansberry, 2009). This means that students who have little or no interest in reading will not be able to force themselves to pick up a book and read for academic purposes, let alone to read for pleasure. This is maintained by UNESCO (1983) who stated that students who do not like to read at an early stage will not adopt reading habit as they grow older.

Another important matter to look at in terms of students reading interests is the differences based on genders. A study conducted by Coles and Hall revealed that 10 to 14 year-old male students read less frequently than female students (2002). Another study showed that more female students reported that they enjoy reading and rate themselves as confident and independent readers (Gambell \& Hunter, 2000). The female students in this study also described that they read for pleasure for 15 minutes or more every day. These research illustrate that female students have higher reading interest compared to male students.

In the Malaysian context, Sapiah (1987) carried out a study on reading interests among year four students. From a sample of 166 students, she discovered there is no significant difference between male and female students in terms of how many books they read in a month. However, in the same study, Sapiah (1987) discovered that there is a significant difference in terms of the choice of genres based on gender. A more recent study by Nor Shariza 
and Amelia revealed that there were some differences between male and female Bachelor of IT and Bachelor of Arts students in terms of their reading habits and reading attitudes (2007).

\section{Methodology}

This study employed the quantitative research as it aimed to establish relationships between variables and look for explanations of the basis of such relationship (Fraenkel \& Wallen, 2008). Apart from that, this study also adopted the correlational approach to gather the data where the relationship between two or more variables was determined (Fraenkel \& Wallen, 2008).

\subsection{Sample}

Simple random sampling technique was utilised when selecting the sample for this study. This is to ensure that every Form Four student has an equal chance of being selected for the study. The researcher believed that the Form Four students who are 16 years old are matured enough to answer the questions given to them as they are now in the middle adolescence (Kagan \& Coles, 1972). During adolescence, adolescents are able to think of abstract things like interests, perspectives and attitudes better (Steinberg, 2005). They are also more likely than children to see things as relative, rather than absolute. Because of this, the Form Four students would be able to give the most accurate answer in terms of their interest in reading. Hence, 86 Form Four students were randomly selected from a list given by the school's principal and it consisted of 22 male students and 64 female students.

\subsection{Instrument}

This research employed a self - administered survey, so the data were collected through a set of questionnaire. The questionnaire used was adapted and adopted from Marrero (2009). After amending and adapting the questionnaire, a pilot study was conducted to determine the reliability of the questionnaire utilized. This pilot study showed that the Cronbach Alpha is .908 which is more than .7. This means the questionnaire is reliable. This questionnaire consisted of two sections. The questionnaire contained bilingual items which were the English language and the Malay language version.

\subsection{Methods of Data Collection}

The data was collected in April during the 2012 academic year in a period of one month. The teachers and students in the school were informed of the study and its reasons. This study was conducted at SMK Belara, Kuala Terengganu. The researcher started the session with a brief explanation on the research such as the purpose and significance of the study. The questionnaire was then distributed to the participants by the researcher herself followed and the names of those who receive the questionnaire were noted for recordkeeping purposes. Although the questionnaire was bilingual where the questions were written in both English and Malay, the researcher was present at the site in order to explain or answer any question from the students to avoid confusion or misunderstanding. Students were given ample time to answer the questions in the questionnaire and the session took approximately 30 minutes. As the researcher was there on site, the questionnaires were collected right after in order to ensure that all students submitted the questionnaires.

\subsection{Methods of Data Analysis}

In order to ensure the data analysis was smoothly run, some of the items in the questionnaire were computed. The first three items in Section B of the questionnaire were computed as 'Students' Reading Interests'. The data obtained from the 6 - item questionnaire were analysed using the statistical analysis software, Statistical Package for the Social Sciences (SPSS) for Windows v17 and presented in the form of related statistical measures including means, standard deviation and independent sample $\mathrm{t}-$ test. 


\section{Results}

\subsection{Students' Reading Interests}

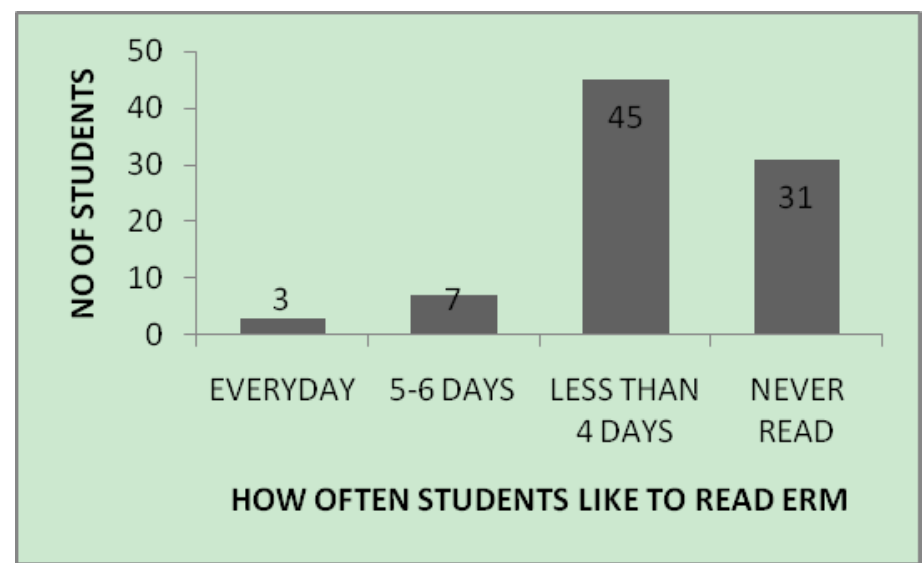

Figure 1. How often students read English Reading Materials (ERM) in a week

From Figure 1, out of 86 students, 45 students read English reading materials less than four times a week. Interestingly, 31 students have never read English reading materials. In addition, there are seven students who read English reading materials for $5-6$ times a week. Finally, three out of 86 students like to read English reading materials every day.

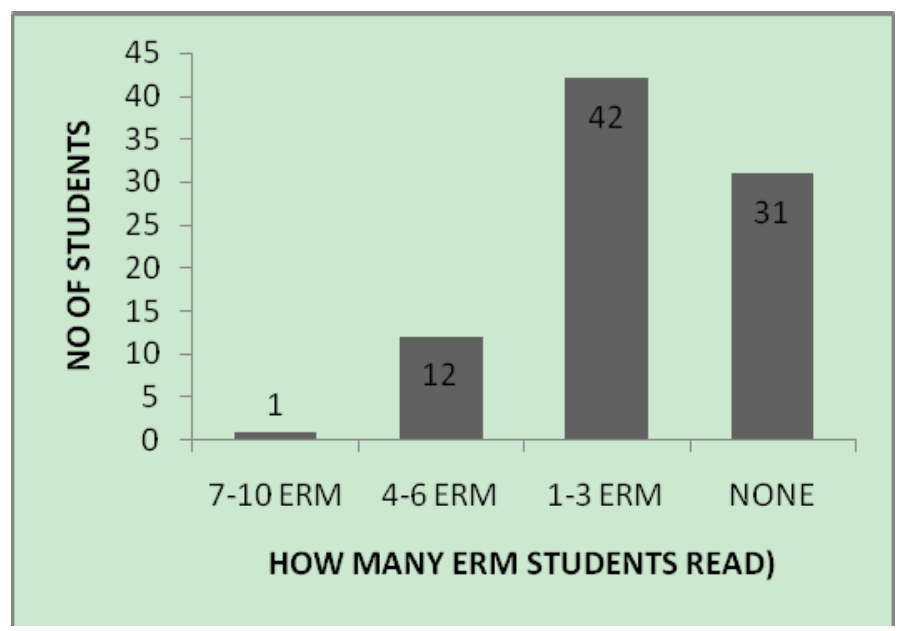

Figure 2. How many English Reading Materials (ERM) students read outside of school compound in April

From Figure 2, out of 86 students, 42 students read 1 - 3 English reading materials in April. Interestingly, 31 students did not read any English reading material in April. In addition, there were 12 students who read $4-6$ English reading materials in April. Finally, one out of 86 students read 7 - 10 English reading materials in April. 


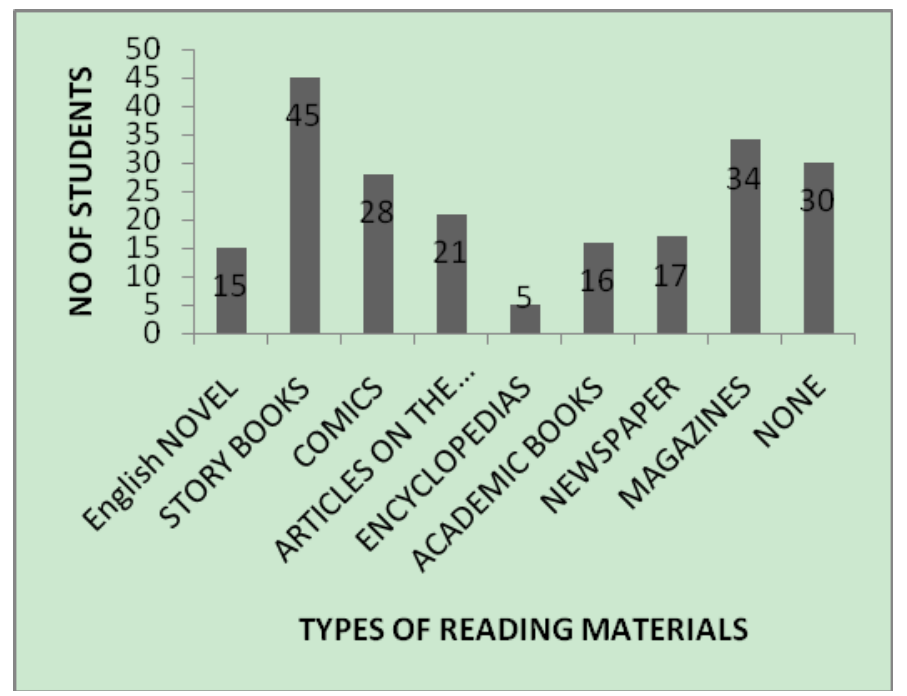

Figure 3. Types of English Reading Materials students like to read

From Figure 3, out of 86 students, 45 students liked to read story books while there were 34 students who liked to read magazines. Interestingly, there were 30 students who did not like to read any type of English reading materials. In addition, there were 28 students who liked to read comics and 21 out of 86 students liked to read articles on the Internet. Besides, the number of students who liked to read newspapers, academic books and English novels were 17, 16 and 15, respectively. Finally, only five students liked to read encyclopaedias.

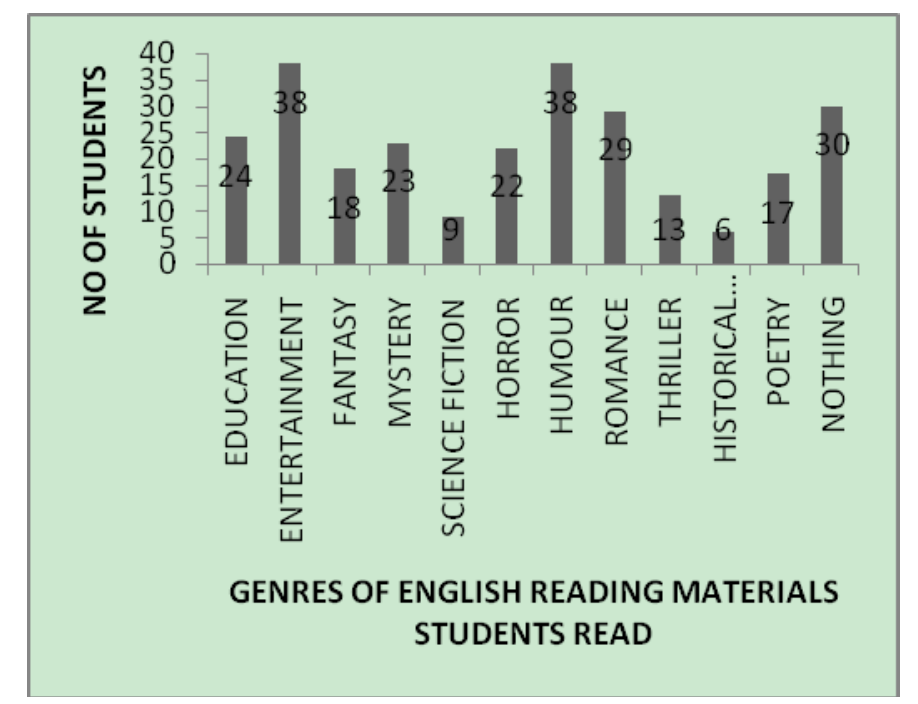

Figure 4. Genres of English Reading Materials students read

From Figure 4, out of 86 students, there were two genres which had the highest number of students which were entertainment and humour with 38 students. Interestingly, there were 30 students who did not like to read any genres of English reading materials. Furthermore, there were 29 students who liked to read English reading materials on romance. In addition, the number of students who liked to read English reading materials on education, mystery and horror were 24,23 and 22 respectively. 18 students liked to read fantasy while the number of students who liked to read English reading materials on poetry was 17. Apart from that, 13 students liked to read English reading materials on thriller whereas nine students liked to read science fiction. Finally, there were only six students who liked to read historical fiction.

Based on the results above, it is apparent that there were still a number of students who did not like to read English reading materials. This was proven as there were still 31 students who have never read English reading 
materials and did not read any English reading materials in April as well as 45 students who only read less than 4 days in a week. This shows that the participants in this study had a relatively low interest in reading English materials. In addition to that, there were a very small number of students who read English reading materials everyday (3 students) and had actually read 7 - 10 English reading materials outside of school in April (1 student). Apart from that, there were a lot of students $(n=30)$ who did not like to read any genres or types of English reading materials. This also shows that the Form Four students in this study still had a relatively low interest in reading English reading materials. In conclusion, the Form Four students in this study did not have high interest towards reading English reading materials.

Table 1. Descriptive statistics of students' reading interests

\begin{tabular}{ll}
\hline Mean & Std. Deviation \\
\hline Students' Reading Interests & 3.0891 .82987 \\
\hline
\end{tabular}

From Table 1, it can be seen that the mean students' reading interests is 3.0891. This means the students in this study neither agree nor disagree on whether they like to read English reading materials.

From the data analysed, although the mean of students' reading interests shows students neither agree nor disagree whether they like to read in a second language, it can be concluded that the Form Four students of SMK Belara had a rather low interest in reading English reading materials as most of them have never read English reading materials and did not have any preferred genres or types of English reading materials.

The findings of this study were similar to those produced by Ley, Schaer and Dismukes (1994) which revealed that students show a remarkable decline in their attitude towards reading as well as how much they read as they age. This is also proven from the Malaysian Reading Profile Survey in 2010 which mentioned that Malaysians above 10 years old read an average of only eight to twelve books a year (National Library of Malaysia, 2010). This is relatively low when compared to other countries like the United States and China (Salim Md. Zain, 2012).

\subsection{Students' Reading Interests Based On Their Gender}

Table 2. Group statistics of students' reading interests (gender)

\begin{tabular}{|c|c|c|c|c|}
\hline & Gender & Mean & Std. Deviation & Std. Error Mean \\
\hline \multirow{2}{*}{ Students' Reading Interests } & Male & 2.7576 & .73594 & .15690 \\
\hline & Female & 3.2031 & .83490 & .10436 \\
\hline
\end{tabular}

Table 2 shows that there was a difference between male and female students' reading interest. The mean for male students was 2.7576 while female students' mean was 3.2031. This meant that female students had a higher interest in reading compared to male students.

Table 3. Independent samples test of students' reading interests (gender)

\begin{tabular}{|c|c|c|c|c|c|c|c|c|c|}
\hline & & \multicolumn{2}{|c|}{$\begin{array}{l}\text { Levene's Test } \\
\text { for Equality } \\
\text { of Variances }\end{array}$} & \multicolumn{6}{|c|}{ t-test for Equality of Means } \\
\hline & & \multirow[t]{2}{*}{$\mathrm{F}$} & \multirow[t]{2}{*}{ Sig. } & \multirow[t]{2}{*}{$\mathrm{t} \quad \mathrm{df}$} & \multirow[t]{2}{*}{$\begin{array}{l}\text { Sig. } \\
\text { (2-tailed) }\end{array}$} & \multirow[t]{2}{*}{$\begin{array}{l}\text { Mean } \\
\text { Difference }\end{array}$} & \multirow[t]{2}{*}{$\begin{array}{l}\text { Std. Error } \\
\text { Difference }\end{array}$} & $\begin{array}{l}95 \% \\
\text { Interval } \\
\text { Differenc }\end{array}$ & $\begin{array}{l}\text { Confidence } \\
\text { of the } \\
\text { ce }\end{array}$ \\
\hline & & & & & & & & Lower & Upper \\
\hline $\begin{array}{l}\text { Students' } \\
\text { Reading } \\
\text { Interests }\end{array}$ & $\begin{array}{l}\text { Equal } \\
\text { variances } \\
\text { assumed }\end{array}$ & .032 & .859 & -2.22284 & .029 & -.44555 & .20051 & -.84428 & -.04682 \\
\hline
\end{tabular}


Levene's Test
for Equality
of Variances

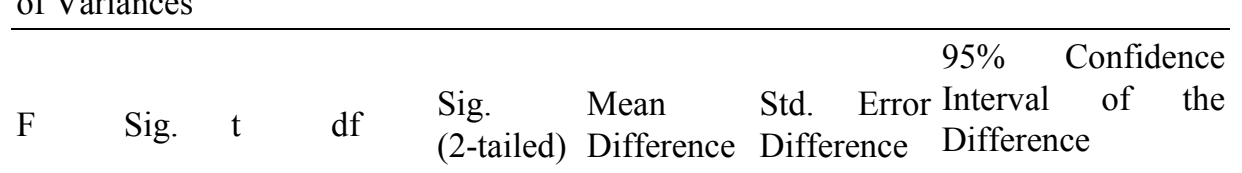

\begin{tabular}{llllllllll} 
& & & & & & & & Lower & Upper \\
Students' & Equal & & & & & & & \\
Reading & variances & .032 & .859 & -2.22284 & .029 & -.44555 & .20051 & -.84428 & -.04682 \\
Interests & $\begin{array}{l}\text { assumed } \\
\text { Equal } \\
\end{array}$ & & & & & & & \\
& $\begin{array}{l}\text { variances } \\
\text { not assumed }\end{array}$ & & -2.364 & 41.016 .023 & -.44555 & .18844 & -.82611 & -.06499 \\
& & & & & & \\
\hline
\end{tabular}

Table 3 shows the independent sample $t$ - test result for students' reading interests based on their gender. This table reveals that the significant value for the Levene's tests is .859 which is more than .05 . This value means the equal variances are assumed. Looking in the Equal Variances assumed row, the $t$ value is -2.222 and the probability in the significant two - tailed column $(\mathrm{p}=.029)$ is less than .05 . This means there is significant difference between male and female students in terms of their reading interests.

In conclusion, Table 2 and Table 3 indicated that there was significant difference in reading interest between male and female students $\mathrm{t}(86)=-2.222, \mathrm{p}-$ value $=.029$. That is, the average mean for female students' reading interest $(\mathrm{M}=3.2031, \mathrm{SD}=.83490)$ is significantly different from that of the male students $(\mathrm{M}=2.7576$, $\mathrm{SD}=.73594)$.

\section{Discussion}

\subsection{Discussion of Results}

Stakeholders such as parents, teachers and school administration must bear in mind that the goal of students' education is to instil the love towards reading as well as lifelong learning. Thus, these are some recommendations for these stakeholders to help in inculcating, developing and enhancing the love towards reading in students as reading is one of the keys to success in both school and life.

From the data analysed, although the mean of students' reading interests shows students neither agree nor disagree whether they like to read in a second language, it can be concluded that the Form Four students of SMK Belara had a rather low interest in reading English reading materials as most of them have never read English reading materials and did not have any preferred genres or types of English reading materials.

The findings of this study were similar to those produced by Ley, Schaer and Dismukes (1994) which revealed that students show a remarkable decline in their attitude towards reading as well as how much they read as they age. This is also proven from the Malaysian Reading Profile Survey in 2010 which mentioned that Malaysians above 10 years old read an average of only eight to twelve books a year (National Library of Malaysia, 2010). This is relatively low when compared to other countries like the United States and China (Salim Md. Zain, 2012). Other than that, the findings were also parallel with the findings found by Kaur and Thivagarajah (1999) who revealed that Malaysian students read very little. Other than that, another research which found that the majority of the students were considered as reluctant readers when it came to reading second language materials (Pandian, 2000) is also similar with the findings of this research. Interestingly, the findings revealed from this study is also alike to one found by Mohamad Jafre, Majid and Ooi (2011) where they found that Malaysian Chinese students still do not adopt reading habits.

The findings of this study are similar to the one conducted by Greenberg, Gilbert and Fredrick (2006) which found that female students outscore male students extensively when it comes to reading practices. A lot of similar studies in United States, Canada and some parts of Europe such as Hall \& Coles (1997), Gambell \& Hunter (2000), and National Centre for Education Statistics (2003) also revealed that female students are better at attaining reading than male students. Furthermore, a study conducted by Coles and Hall revealed that $10-14$ year old male students read less frequently than female students (2002). Another study showed that more female students reported that they enjoy reading and rate themselves as confident and independent readers (Gambell \& Hunter, 2000). The female students in this study also described that they read for pleasure for 15 minutes or 
more every day. Besides, the finding of this study is also similar to a study conducted by Sapiah (1987) who mentioned there is a significant difference in terms of the choice of genres based on gender. However, Sapiah also stated that there is no significant difference between male and female students in terms of how many books they read in a month. The findings of this study are also similar to the one found by Nor Shariza and Amelia where they found that there were some differences between male and female students in terms of their reading habits and reading attitudes (2007).

However, the result of this study could not be generalized to all Form Four students in Kuala Terengganu as the scope of the study was limited to the respondents of the survey, Form Four students in Sekolah Menengah Kebangsaan Belara (SMK Belara), Kuala Terengganu, Terengganu and centred on students' reading interests of the Form Four students enrolled in this school. Hence, it might not have external validity as students from other schools in other districts or states might respond differently to the survey as other factors might influence the findings of such a study. These factors could be the students' locality, either urban or rural, the school location, parental involvement, economic status and the social environment. However, it is hoped that the study would be able to enlighten those with the same background.

\subsection{Recommendations for Parents}

The result shows that students have low level of reading interests in reading English reading materials. As parents know that their children do not like reading English reading materials, they can encourage their children to like reading by reading aloud to and with their children as it is enjoyable. By doing this, they can share their thoughts on the readings while reading them to their children. In addition to that, parents could also ask their children to share their thoughts on the readings. It is hoped that children would develop their love and interests towards reading. Other than that, this study also revealed that students have different interests they choose their reading materials. Therefore, parents could also provide students with a wide range of reading materials by supplying the materials at home. In order to do this, parents should find out their children's interests. For instance, if parents find out that their children like rugby and love to play rugby, they might want to find a book entitled 101 Youth Rugby Drills (101 Drills) (Sheryn, 2011) to their children. By doing this, parents could help to develop and enhance their children's interests in reading especially towards English reading materials.

\subsection{Recommendations for Teachers and School Administration}

Teachers and the school administration can also contribute in encouraging students to like reading English reading materials. For instance, teachers could provide some time for students to read either on their own silently or with the whole class before starting the lesson like Sustained Silent Reading (Hartness, 2006). During this program, students must read easy and enjoyable reading materials. As a result, students would develop the love towards reading. As this result shows that students have different interests in the content of the reading materials, teachers and school administration could also provide students with a wide range of reading materials in the class, library or any reading corners in the school. In order to do this, teachers or school administration could conduct a survey to find out students' interests and as a result, they can find reading materials which match students' interests. For instance, if there are students in the school who play rugby, they might want to suggest a book entitled 101 Youth Rugby Drills (101 Drills) (Sheryn, 2011) to their students. By doing this, teachers and school administration could develop and enhance students' interests in reading especially towards English reading materials.

\section{Acknowledgement}

My greatest gratitude goes to my parents and family who have been very supportive and encouraging while this study was conducted. I would like to also express my gratitude to the Form Four students (2011) of SMK Belara for participating in this study as well as the school administration and teachers who gave their permission to me in conducting this study.

\section{References}

Abd Wahab Bin Mat. (1995). Hubungan Minat Membaca Di Kalangan Pelajar- Pelajar SMKA Di Seberang Perai Dengan Latar Belakang Keluarga Dan Persekitaran. (Thesis, 1995)

Anderson, R., Fielding, L., \& Wilson, P. (1988).Growth In Reading and How Children Spend Their Time Outside Of School. Reading Research Quarterly, 23, 285-303. http://dx.doi.org/10.1598/RRQ.23.3.2

Bandura, A. (1977). Social Learning Theory. New York: General Learning Press.

Coles, M., \& Hall, C. (2002). Gendered readings: Learning from children's reading choices. Journal of Research in Reading, 25, 96-108. http://dx.doi.org/10.1111/1467-9817.00161 
Eskey, D. E. (2002). Reading and the Teaching of L2 Reading. TESOL Journal, 7(1), 5-9.

Fraenkel, J. R., \& Wallen, N. E. (2008). How to design and evaluate research in education (7th ed.). New York, NY: McGraw Hill.

Gambell, T., \& Hunter, D. (2000). Surveying gender differences in Canadian school literacy. Journal of Curriculum Studies, 32, 689-719. http://dx.doi.org/10.1080/00220270050116941

Grabe, W. (2003). Reading-writing relations: L2 perspectives on research and practice. In B. Kroll (Ed.), Research on second-language writing (pp. 242-262). New York: Cambridge University Press.

Greenberg, D., Gilbert, A., \& Fredrick, L. (2006). Reading interest and behaviour in middle school students in inner-city and rural settings. Reading Horizons, 47(2), 159-174.

Guthrie, J. T., \& Wigfield, A. (2000). Engagement and motivation in reading. In M. L. Kamil, \& P. B. Mosenthal (Eds.), Handbook of reading research (Vol. 11l, pp. 403-422). Mahwah, NJ: Lawrence Erlbaum Associates.

Hall, C., \& Coles, M. (1997). Gendered readings: Helping boys develop as critical readers. Gender and Education, 9, 61-68. http://dx.doi.org/10.1080/09540259721457

Hartness, D. (2006). Sustained Silent Reading Program. Retrieved August 8, 2011, from http://www.newberry.k12.sc.us/nbhs/literacypage/Sustained\%20Silent\%20Reading\%20Program.pdf

Imran Ariff Bin Mohd Ariffin. (2010). Tabiat Membaca Di Kalangan Pelajar Kemahiran Hidup Di Universiti Pendidikan Sultan Idris (Thesis, 2010).

Kagan, J., \& Coles, R. (Eds.). (1972). Twelve To Sixteen: Early Adolescence. New York: Norton.

Kaur, S., \& Thivagarajah, R. (1999). The Reading Habits of ELLS Students in University Science Malaysia. Retrieved from http://www.ultibased.rmit.edu.au/Articles/Aug01/kaur.htm

Ley, T., Schaer, B., \& Dismukes, B. (1994). Longitudinal study of the reading attitudes and behaviours of middle school students. Reading Psychology: An International Quarterly, 15, 11-38. http://dx.doi.org/10.1080/0270271940150102

Marohaini Yusuff. (1989). Strategi Pengajaran Bacaan dan Kefahaman. Kuala Lumpur: Karya Bistari Sdn. Bhd.

Marrero, L. M. (2009). Reading attitudes, habits and performance of third grade ESL students participating in a reading challenge program. Retrieved June 10, 2011, from http:/grad.uprm.edu/tesis/martinezmarrero.pdf

McKenna, M., \& Kear, D. (1990). Measuring attitude toward reading: A new tool for teachers. The Reading Teacher, 43, 626-639. http://dx.doi.org/10.1598/RT.43.8.3

McKool, S. (2007). Factors that influence the decision to read: An investigation of fifth grade students' out-of-school reading habits. Reading Improvement, 44(3), 111-132.

Melville, S. (2002). The Knitting Experience Book 1: The Knit Stitch, Inspiration \& Instruction. South Dakota, USA: XRX Books Publishing.

Mohamad Jafre Zainol Abidin, Majid Pour-Mohammadi, \& Ooi, C. L. (2011). The Reading Habits of Malaysian Chinese University Students. Journal of Studies in Education. http://dx.doi.org/10.5296/jse.v1i1.1037

National Center for Educational Statistics. (2003). The Nation's Report Card: Reading Highlights, 2002. Retrieved June 10, 2011, from http://nces.ed.gov/nationasreportcard

National Library of Malaysia. (1998). Reading profile of Malaysians: 1996. Kuala Lumpur: Perpustakaan Negara Malaysia. Retrieved August 16, 2011, from http://www.pnm.gov.my

National Library of Malaysia. (2010). Reading profile of Malaysians: 2010. Kuala Lumpur: Perpustakaan Negara Malaysia. Retrieved August 16, 2011, from http://www.pnm.gov.my

Nor Shariza Abdul Karim, \& Amelia Hassan. (2007). Reading Habits and Attitude in the Digital Age: Analysis of Gender and Academic Program Differences in Malaysia. The Electronic Library, 25(3), 285-298. http://dx.doi.org/10.1108/02640470710754805

Nunan, D. (1999). Second language teaching and learning. Boston: Heinle and Heinle.

Pandian, A. (2000). A Study on Readership Behaviour among Multi-Ethnic, Multi-Lingual Malaysian Students. Paper presented at the $8^{\text {th }}$ International Literacy and Educational Research Network (LERN) Conference on Learning, RMIT University, Melbourne, July 5-9. 
Safiah Osman. (1990). Membaca: Satu Pengenalan. Kuala Lumpur: Berita Publishing Sdn. Bhd.

Salim Md. Zain. (2012). Budaya Ilmu dalam Kalangan Rakyat Malaysia.Retrieved February 20, 2012, from http://klikweb.dbp.my/?p=1254

Sapiah Hamid. (1987). Menilai Minat Membaca Di Kalangan Murid Tahun IV Berdasarkan Pemilihan Bahan Bacaan. Jurnal Pendidikan, 11, 135-136.

Sheryn, C. (2011). 101 Youth Rugby Drills (101 Drills). London, United Kingdom: A \& C Black Publishers Ltd.

Stanovich, K. (1986). Matthew effects in reading: Some consequences of individual differences in the acquisition of literacy. Reading Research Quarterly, 21, 360-406. http://dx.doi.org/10.1598/RRQ.21.4.1

Stansberry, G. (2009). Benefits of Reading (or Ways Reading Makes You Better at Life). Retrieved January 19, 2011, from http://lifedev.net/2009/06/reading-makes-you-better/

Steinberg, L. (2005). Adolescence (7th ed.). New York: McGraw-Hill.

Taylor, B. M., Frye, B. J., \& Maruyama, G. (1990). Time spent reading and reading growth. American Educational Research Journal, 27, 351-362. http://dx.doi.org/10.3102/00028312027002351

UNESCO. (1983). Galakan Membaca Untuk Kanak-Kanak dan Remaja. Kuala Lumpur: Dewan Bahasa dan Pustaka.

United States Department of Education (2005). Helping your child become a reader. Washington, DC: ED Pubs.

Walberg, H. J., \& Tsai, S. L. (1985). Correlates of reading achievement and attitude: A national assessment study. Journal of Educational Research, 78(3), 159-167.

Wallace, C. (1992). Reading. Oxford: Oxford University Press.

Wallace, C. (2007). Vocabulary: The key to teaching English language learners to read. Reading Improvement, 44(A), 189-193.

\section{Copyrights}

Copyright for this article is retained by the author(s), with first publication rights granted to the journal.

This is an open-access article distributed under the terms and conditions of the Creative Commons Attribution license (http://creativecommons.org/licenses/by/3.0/). 